\title{
Comparison of effects of high and low dose paracetamol treatment and toxicity on brain and liver in rats
}

\author{
(1) Ersoy Oksuz, ${ }^{1}$ (i) Semih Yasar, ${ }^{2}$ (i) Remzi Erten, ${ }^{3}$ (i) Okan Arihan, ${ }^{4}$ (i) Gokhan Oto $^{1}$ \\ ${ }^{1}$ Department of Medical Pharmacology, Van Yuzuncu Yil University Faculty of Medicine, Van, Turkey \\ ${ }^{2}$ Department of Medical Laboratory Technics, Van Yuzuncu Yil University Ozalp Vocational High School, Van, Turkey \\ ${ }^{3}$ Department of Medical Pathology, Van Yuzuncu Yil University Faculty of Medicine, Van, Turkey \\ ${ }^{4}$ Department of Medical Physiology, Van Yuzuncu Yil University Faculty of Medicine, Van, Turkey
}

\begin{abstract}
OBJECTIVE: Paracetamol is thought that it acts by inhibiting the central cyclooxygenase (COX) enzyme; its mechanism of action is still not fully explained. Although its most important side effect is hepatoxicity, it is thought to cause toxicity on the brain in recent years. The present study aims to investigate the treatment and toxic effects of low and high doses of paracetamol on the liver and brain.

METHODS: Wistar-albino rats were used in this study. At doses of $20-500 \mathrm{mg} / \mathrm{kg}$, paracetamol was administered intraperitoneally once a day for one and three days. The brain and liver were used for immunohistochemical evaluation using COX-3, prostaglandin $E_{2}\left(P_{2}\right)$ and caspase 3 antibodies and for total antioxidant (TAS), total oxidant (TOS) and oxidative stress index (OSI) measurements. Results were evaluated using the Kruskal Wallis test (SPSS ver.24).

RESULTS: The liver COX-3 levels were significantly lower in both groups with higher doses $(p<0.05)$. In the brain, there was no statistically significant difference in COX-3 levels between the groups. There was no statistically significant difference in $\mathrm{PGE}_{2}$ levels in the liver and brain between the groups ( $p>0.05$ ). The caspase 3 level in the liver was statistically significantly higher in the low dose group compared to the other groups $(p<0.05)$. In both liver and brain, OSI values were significantly higher in the 3-day high-dose group compared to others $(p<0.05)$. There was no statistically significant difference between the groups in ALT and AST values ( $p>0.05)$.

CONCLUSION: The results of our study show that paracetamol inhibits the COX-3 enzyme in the liver but has no effect in the brain, and COX-3 does not have an effect on PGE $_{2}$. Paracetamol causes apoptosis in the liver only in low doses; higher doses may cause toxicity by increasing oxidative stress, especially in the brain.
\end{abstract}

Keywords: Apoptosis; oxidative stress; paracetamol.

Cite this article as: Oksüz E, Yasar S, Erten R, Arihan O, Oto G. Comparison of effects of high and low dose paracetamol treatment and toxicity on brain and liver in rats. North Clin Istanb 2020;7(6):541-550.

$\mathrm{P}$ aracetamol is one of the most widely used drugs in the world as analgesics and antipyretics. Although it has been classified as non-steroidal anti-inflammatory drugs (NSAIDs) for many years, it has been classified as "other" analgesic and antipyretic drugs in recent years due to lack of anti-inflammatory properties. Although it acts by inhibiting the cyclooxygenase (COX) enzyme and prostaglandin synthesis, such as NSAIDs, several studies have shown that the potential for inhibition of COX enzymes in peripheral tissues is quite low [1]. Therefore, 
it is thought to act by inhibiting the COX enzyme found in the central nervous system (CNS). Various studies conducted for this purpose suggest that it inhibits COX3 enzyme, which is a variant of COX-1 and expressed in the brain, but in different studies, the opposite has been claimed [2-4]. Again, in other studies, it has been shown that no peripheral effect is apparent since it binds to different regions of COX enzyme in the CNS [1].

The most important side effect of paracetamol is hepatotoxicity. It is mainly metabolized in the liver to sulfate and glucuronic acid [5]. A small part of it undergoes oxidative metabolism with CYP450 enzyme systems and becomes $\mathrm{N}$ acetyl benzokinonimine (NAB). This metabolite formed under normal conditions is converted to cysteine and mercaptopurine by glutathione. However, if taken in large amounts, the amount of NAB increases, and glutathione depots in hepatocytes decrease. When the glutathione stores fall below $30 \%$ of the normal value, hepatic damage begins. In addition, NAB, which cannot be metabolized, reacts with DNA, protein and lipids in the cells and causes cell necrosis [6]. However, various studies have shown that many different mechanisms, such as reactive oxygen species (ROS), calcium increase and intracellular signaling pathways mediate hepatotoxicity, caused by paracetamol [7-9]. Another organ with paracetamol toxicity is the brain. This damage is usually secondary to hepatic encephalopathy (HE) due to increased ammonia as a result of acute liver failure (ARF) [10]. However, CYP2E1enzyme, which breaks down paracetamol in the liver and causes the formation of a toxic metabolite, is very common in the CNS [11]. In addition, in low and high doses, paracetamol is widely distributed throughout the CNS by easily crossing the blood-brain barrier [12]. Thus, it has been suggested that, especially at high doses, it may have a direct toxic effect independent of liver toxicity. For example, in rats with oral toxic dose paracetamol administration, it has been shown that glutathione decreases and oxidative stress increases in almost every region of CNS [13]. However, there are also studies with different findings. Low-dose paracetamol has been shown to have a neuroprotective effect by reducing ROS [14]. In another study, the findings showed that paracetamol has a cytoprotective effect in neuron cells [15].

In this study, the effects of high-dose and low-dose paracetamol administration on oxidative stress, COX-3, prostaglandin $\mathrm{E}_{2}\left(\mathrm{PGE}_{2}\right)$ levels, apoptosis and biochemical parameters in rat liver and brain were investigated.

\section{MATERIALS AND METHODS}

\section{Chemicals}

Paracetamol, $1000 \mathrm{mg} / 100 \mathrm{ml}$ Intravenous (IV) (Paracerol, Polifarma, TURKEY). COX-3 rabbit polyclonal IgG antibody $100 \mathrm{ul}-1 \mathrm{ug} / \mathrm{ul}$ (Bioss antibodies, USA). $\mathrm{PGE}_{2}$, rabbit polyclonal $\mathrm{IgG}$ antibody $100 \mathrm{ul}-1 \mathrm{ug} / \mathrm{ul}$ (Bioss antibodies, USA). Caspase-3, CPP32 colorimetric assay kit (BioVision Research Products, USA).

\section{Experimental Protocol}

This study was approved by the animal ethics committee of Van Yuzuncu Yil University (Decision no: 2017/06). Male Wistar-albino rats weighing 200-250 g were used in this study. Rats were fed with standard feed and tap water. They were kept in 12 hours of light, 12 hours of dark. Five different groups were formed with eight rats in each group and paracetamol was administered as follows.

1. Control Group (C): Saline was administered.

2. Low dose 1-day group (LD1): Paracetamol $20 \mathrm{mg} / \mathrm{kg}$ single dose was administered intraperitoneally.

3. High dose 1-day group (HD1): Paracetamol 500 $\mathrm{mg} / \mathrm{kg}$ single dose was administered intraperitoneally.

4. Low dose 3-day group (LD3): Paracetamol $20 \mathrm{mg} /$ $\mathrm{kg} /$ day was administered intraperitoneally once a day for three days.

5. High-dose 3-day group (HD3): Paracetamol was administered intraperitoneally once daily for three days at $500 \mathrm{mg} / \mathrm{kg} /$ day.

Rats were sacrificed under anesthesia $(80 \mathrm{mg} / \mathrm{kg}$ ketamine) 24 hours later in single-dose groups 24 hours after the $3^{\text {rd }}$-day dose. Following sacrification, blood samples, brain and liver were obtained. The brain and liver were cut in half from the midline and half of them were used for histopathological evaluation in neutral buffered $10 \%$ formalin solution, and the other half was stored at $-20 \mathrm{C}^{\circ}$ for TAS, TOS and OSI measurements.

\section{Histopathological Evaluation}

Liver and brain samples were fixed in paraffin blocks after fixation with $10 \%$ formalin. Four micrometer sections were taken from the blocks and hematoxylin eosin was evaluated by light microscope after staining.

Immunohistochemistry COX-3, $\mathrm{PGE}_{2}$ and Caspase-3 After 24 hours of fixation, tissues were embedded in paraffin blocks after being processed by Leica $\mathrm{ASP}^{\circledR} 300$ 
(Leica MICROSYSTEMS, GERMANY) automated vacuum tissue tracking device for light microscopy examination. Slices were obtained from the paraffin blocks with the microtome device and immunohistochemical staining was performed (Leica RM ${ }^{\circledast}$ 2135-Leica MICROSYSTEMS, GERMANY).

Sections taken for immunohistochemical examination were transferred on polylysine slides and $\mathrm{PGE}_{2}$, COX -3 and Caspase- 3 were used as primary antibodies. These antibodies were used for staining with Ventana Benchmark XT immunohistochemistry automated staining system and Ventana ultraView Alkaline Phosphatase Red Detection Kit under appropriate positive controls, followed by evaluation of staining of PGE, COX -3 and Caspase- 3 in brain and liver cells as follows:

Staining prevalence: $0:$ no stained cells, $1+:$ less than $20 \%, 2+$ : between $20 \%-50 \%, 3+$ : more than $50 \%$. Staining Density: 0: No staining, 1+: Poor staining, 2+: Moderately strong staining, $3+$ : Strong staining. Total Score: The sum of the scores obtained from the staining prevalence and staining intensity. Low: 0-3 (Low expression staining), High: 4-6 (High expression staining). Caspase 3 : Number of positive stained cells in $10 \times 200$ areas.

\section{Oxidative Stress Level}

Total Antioxidant Status (TAS), Total Oxidant Status (TOS) and Oxidative Stress Index (OSI) Analysis

TAS levels were measured by automated measurement using a kit containing 2,2 "-Azinobis (3-ethylbenzothiazoline 6-sulfonic acid). The results were expressed as mmolTrolox ${ }^{\circledast} \mathrm{q} / \mathrm{L}$.TOS levels; The color change after oxidation of $\mathrm{Fe}^{+2}$ to $\mathrm{Fe}^{+3}$ was measured by the TOS method based on spectrophotometric measurement of the amount of oxidant substances [16]. The results were expressed as mol $\mathrm{H}_{2} \mathrm{O}_{2} \mathrm{q} / \mathrm{L}$. The ratio of TOS to TAS is defined as OSI and is a marker of oxidative stress. The OSI value was calculated according to the following formula. OSI (arbitrary unit $)=\left[\operatorname{TOS}\left(\mu \mathrm{mol} \mathrm{H}_{2} \mathrm{O}_{2} \mathrm{Eq} / \mathrm{L}\right) /\right.$ TAS $(\mu \mathrm{mol}$ TroloxEq/L) $\times 10]$ [17].

\section{Biochemical Parameters}

ALT, AST determinations in serum samples were performed using a commercial kit (Roche, Germany) on a Hitachi/P800 modular auto analyzer (Roche, Germany).

\section{Statistical Analysis}

Descriptive statistics for continuous variables in our
TABLE 1. COX-3 level in the liver

\begin{tabular}{lccc} 
Groups liver* & $\begin{array}{c}\text { Prevalence \% } \\
\text { Mean } \pm \text { SD }\end{array}$ & $\begin{array}{c}\text { Density } \\
\text { Mean } \pm S D\end{array}$ & $\begin{array}{c}\text { Total score } \\
\text { Mean } \pm S D\end{array}$ \\
\hline C & $4.13 \pm 1.73^{\mathrm{ab}}$ & $3.00 \pm 0.00^{\mathrm{a}}$ & $4.00 \pm 0.00^{\mathrm{a}}$ \\
LD1 & $2.38 \pm 1.51^{\mathrm{bc}}$ & $2.87 \pm 0.35^{\mathrm{a}}$ & $3.87 \pm 0.35^{\mathrm{a}}$ \\
HD1 & $3.00 \pm 2.93^{\mathrm{abc}}$ & $2.00 \pm 1.07^{\mathrm{b}}$ & $3.00 \pm 1.07^{\mathrm{b}}$ \\
LD3 & $4.71 \pm 2.69^{\mathrm{a}}$ & $3.00 \pm 0.00^{\mathrm{a}}$ & $4.00 \pm 0.00^{\mathrm{a}}$ \\
HD3 & $1.63 \pm 0.74^{\mathrm{c}}$ & $2.13 \pm 0.99^{\mathrm{b}}$ & $3.13 \pm 0.99^{\mathrm{b}}$ \\
p & $\mathbf{0 . 0 0 6}$ & $\mathbf{0 . 0 1 8}$ & $\mathbf{0 . 0 2 0}$ \\
\hline
\end{tabular}

SD: Standard deviation; C: Control; LD1: Low dose 1-day group; HD1: High dose 1-day group; LD3: Low dose 3-day group; HD3: High-dose 3-day group (HD3) $(p<0.05) ; a, b, c$ : Shows statistically significant difference between groups; $*$ : The prevalence score is $1.00 \pm 0.00$ for all groups.

TABLE 2. COX-3 level in the brain

\begin{tabular}{lccc} 
Groups brain* & $\begin{array}{c}\text { Prevalence \% } \\
\text { Mean } \pm \text { SD }\end{array}$ & $\begin{array}{c}\text { Density } \\
\text { Mean } \pm \text { SD }\end{array}$ & $\begin{array}{c}\text { Total score } \\
\text { Mean } \pm S D\end{array}$ \\
\hline C & $2.25 \pm 1.83$ & $3.00 \pm 0.00$ & $4.00 \pm 0.00$ \\
LD1 & $1.75 \pm 0.71$ & $2.63 \pm 0.74$ & $3.63 \pm 0.74$ \\
HD1 & $2.25 \pm 1.67$ & $2.75 \pm 0.71$ & $3.75 \pm 1.71$ \\
LD3 & $1.38 \pm 0.52$ & $2.38 \pm 0.74$ & $3.38 \pm 0.74$ \\
HD3 & $1.50 \pm 0.53$ & $2.50 \pm 0.76$ & $3.50 \pm 0.76$ \\
p & 0.694 & 0.217 & 0.217 \\
\hline
\end{tabular}

SD: Standard deviation; C: Control; LD1: Low dose 1-day group; HD1: High dose 1-day group; LD3: Low dose 3-day group; HD3: High-dose 3-day group (HD3); *: The prevalence score is $1.00 \pm 0.00$ for all groups.

study were expressed as Median, Mean, Standard Deviation, Minimum and Maximum values. For categorical variables, they were expressed as Number and Percentage. Kruskal-Wallis test was used to compare group means concerning continuous variables. Relevant post hoc tests were used to determine different groups. A chi-square test was used to determine the relationship between groups and categorical variables. The statistical significance level was set as $5 \%$ and SPSS (ver.24) statistical package program was used for the calculations.

\section{RESULTS}

The rats in the HD3 group had significantly reduced activities, such as eating and drinking water, compared to 

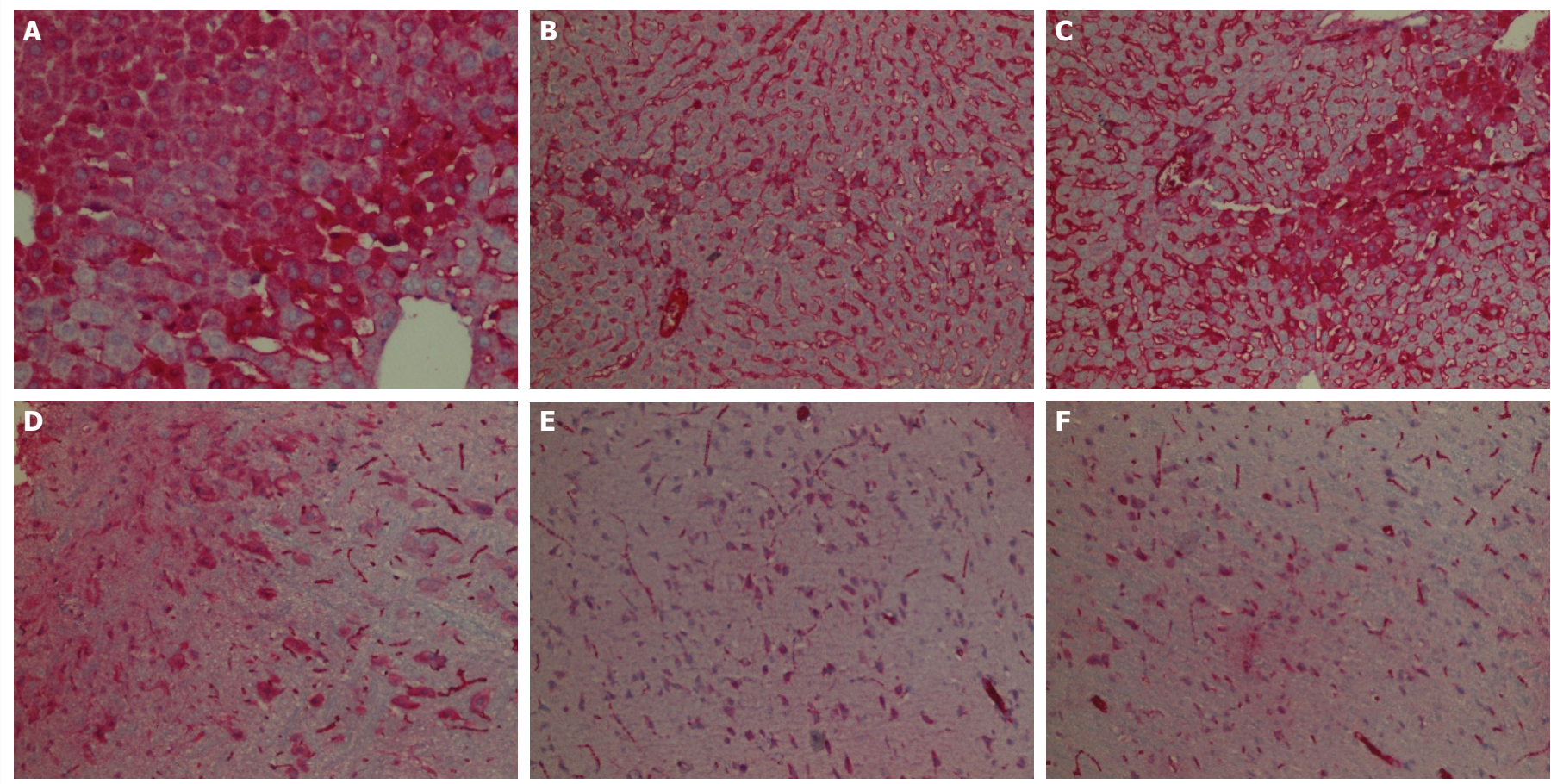

FIGURE 1. COX-3 in the liver, (A) Control group (B) High dose 1 day group (C) High dose 3 day group. COX-3 level in both groups significantly lower then control $p<0.05$. COX-3 in the brain, (D) Control group (E) High dose 1 day group (F) High dose 3 day group. There is no statistically significant difference between groups ( $p>0.05)$. Immunohistochemical staining ( $x 200$ Magnification).

\begin{tabular}{lccc}
\multicolumn{4}{l}{ TABLE 3. PGE level in the liver } \\
Groups liver* & $\begin{array}{c}\text { Prevalence \% } \\
\text { Mean } \pm \text { SD }\end{array}$ & $\begin{array}{c}\text { Density } \\
\text { Mean } \pm \text { SD }\end{array}$ & $\begin{array}{c}\text { Total score } \\
\text { Mean } \pm S D\end{array}$ \\
\hline C & $4.38 \pm 2.00$ & $3.00 \pm 0.00$ & $4.00 \pm 0.00$ \\
LD1 & $3.13 \pm 1.64$ & $2.63 \pm 0.52$ & $3.63 \pm 0.52$ \\
HD1 & $2.63 \pm 1.30$ & $2.50 \pm 0.76$ & $3.50 \pm 0.76$ \\
LD3 & $4.00 \pm 2.00$ & $3.00 \pm 0.00$ & $4.00 \pm 0.00$ \\
HD3 & $2.50 \pm 2.00$ & $2.63 \pm 0.74$ & $3.63 \pm 0.74$ \\
P & 0.154 & 0.169 & 0.171 \\
\hline
\end{tabular}

SD: Standard deviation; C: Control; LD1: Low dose 1-day group; HD1: High dose 1-day group; LD3: Low dose 3-day group; HD3: High-dose 3-day group (HD3); *: The prevalence score is $1.00 \pm 0.00$ for all groups.

the other groups. There was also a significant reduction and inactivity in night activities.

When the liver COX-3 level was evaluated according to the total score, it was statistically significantly lower in both groups with high doses $(p<0.05)$. There was no statistically significant difference in COX-3 levels between the groups in the brain ( $p>0.05)$ (Table 1, 2, Fig. 1).
TABLE 4. $\mathrm{PGE}_{2}$ level in the brain

\begin{tabular}{lccc} 
Groups brain* & $\begin{array}{c}\text { Prevalence \% } \\
\text { Mean } \pm \text { SD }\end{array}$ & $\begin{array}{c}\text { Density } \\
\text { Mean } \pm \text { SD }\end{array}$ & $\begin{array}{c}\text { Total score } \\
\text { Mean } \pm \text { SD }\end{array}$ \\
\hline C & $6.63 \pm 4.00^{\mathrm{a}}$ & $3.00 \pm 0.00$ & $4.00 \pm 0.00$ \\
LD1 & $5.88 \pm 3.60^{\mathrm{a}}$ & $2.87 \pm 0.35$ & $3.87 \pm 0.35$ \\
HD1 & $3.88 \pm 1.46^{\text {ab }}$ & $2.75 \pm 0.46$ & $3.75 \pm 0.46$ \\
LD3 & $2.50 \pm 1.20^{\mathrm{b}}$ & $2.87 \pm 0.35$ & $3.87 \pm 0.35$ \\
HD3 & $2.38 \pm 1.06^{\mathrm{b}}$ & $3.00 \pm 0.00$ & $4.00 \pm 0.00$ \\
p & $\mathbf{0 . 0 3 6}$ & 0.435 & 0.433 \\
\hline
\end{tabular}

SD: Standard deviation; C: Control; LD1: Low dose 1-day group; HD1: High dose 1-day group; LD3: Low dose 3-day group; HD3: High-dose 3-day group (HD3) $(p<0.05) ; a, b, c:$ Shows statistically significant difference between groups. $*$ : The prevalence score is $1.00 \pm 0.00$ for all groups.

When the $\mathrm{PGE}_{2}$ level was evaluated according to the total score, there was no statistically significant difference in both liver and brain $(p>0.05)$. Only the staining prevalence in the brain was statistically lower in LD3 and HD3 groups compared to control and LD1 groups ( Tables 3, 4, Fig. 2).

The levels of caspase 3 in the liver were significantly 

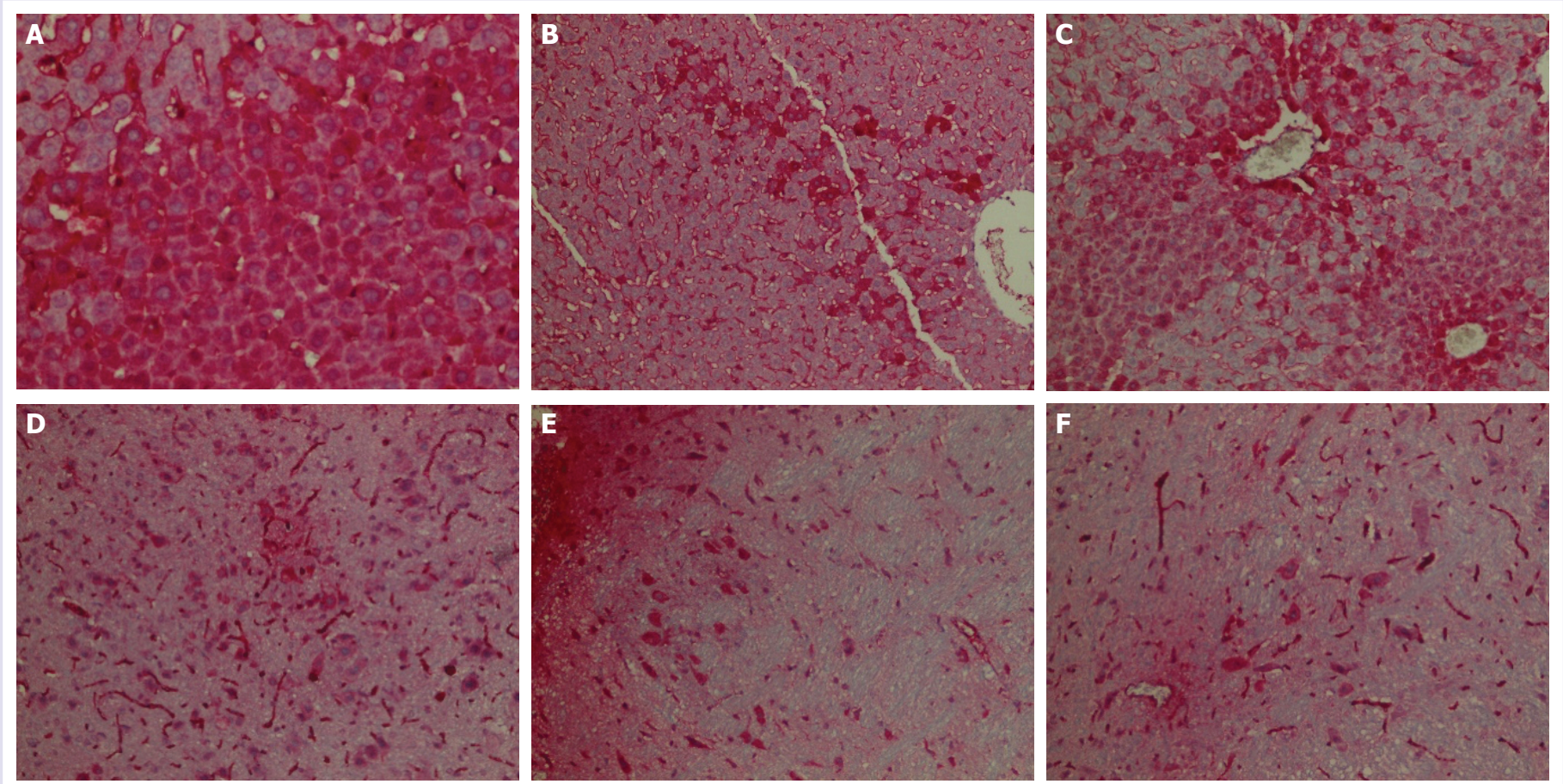

FIGURE 2. PGE in the liver, (A) Control group (B) High dose 1 day group (C) High dose 3 day group. PGE $_{2}$ in the brain, (D) Control group (E) High dose 1 day group (F) High dose 3 day group. There is no statistically significant difference between groups in both the liver and brain $p>0.05$. Immunohistochemical staining (x200 Magnification).

TABLE 5. Caspase 3 level in the liver and the brain

\begin{tabular}{lcccccc} 
Caspase 3 & $\begin{array}{c}\mathrm{C} \\
\text { Mean } \pm \text { SD }\end{array}$ & $\begin{array}{c}\text { LD1 } \\
\text { Mean } \pm \text { SD }\end{array}$ & $\begin{array}{c}\text { HD1 } \\
\text { Mean } \pm \text { SD }\end{array}$ & $\begin{array}{c}\text { LD3 } \\
\text { Mean } \pm \text { SD }\end{array}$ & $\begin{array}{c}\text { HD3 } \\
\text { Mean } \pm \text { SD }\end{array}$ & p \\
\hline Liver & $0.75 \pm 0.71^{\mathrm{b}}$ & $1.13 \pm 0.64^{\mathrm{a}}$ & $0.75 \pm 0.71^{\mathrm{b}}$ & $1.86 \pm 0.90^{\mathrm{a}}$ & $0.63 \pm 0.52^{\mathrm{b}}$ & $\mathbf{0 . 0 4 1}$ \\
Brain & $0.00 \pm 0.00$ & $0.25 \pm 0.46$ & $0.38 \pm 0.52$ & $0.25 \pm 0.46$ & $0.25 \pm 0.46$ & 0.498 \\
\hline
\end{tabular}

SD: Standard deviation; C: Control; LD1: Low dose 1-day group; HD1: High dose 1-day group; LD3: Low dose 3-day group; HD3: High-dose 3-day group (HD3) $(p<0.05) ; a, b$, c: Shows statistically significant difference between groups.

higher in the LD1 and LD3 groups compared to the other groups $(\mathrm{p}<0.05)$. In the brain, there was no statistically significant difference between the groups at the caspase 3 level ( $p>0.05)$ (Table 5, Fig. 3). Hematoxylin eosin staining showed no liver and brain tissue necrosis (Fig. 4).

The levels of TAS in the liver were significantly higher in the high-dose paracetamol group compared to the control and 24-hour low-dose paracetamol group $(\mathrm{p}<0.05)$. TOS levels were significantly higher in the group treated with high dose paracetamol for only three days compared to the other groups $(\mathrm{p}<0.05)$ (Table 6).
OSI values were also significantly higher in the group administered with high dose paracetamol for three days, similar to TOS $(p<0.05)$. In contrast to the liver, TAS levels in the brain were significantly lower in the high-dose groups than in the other groups $(p<0.05)$. TOS and OSI levels were significantly higher in the group treated with high dose paracetamol for only three days compared to the other groups similar to the liver $(\mathrm{p}<0.05)$ (Table 6). There was no statistically significant difference in ALT and AST values between control and paracetamol treated groups $(p>0.05)$ (Table 7$)$. 

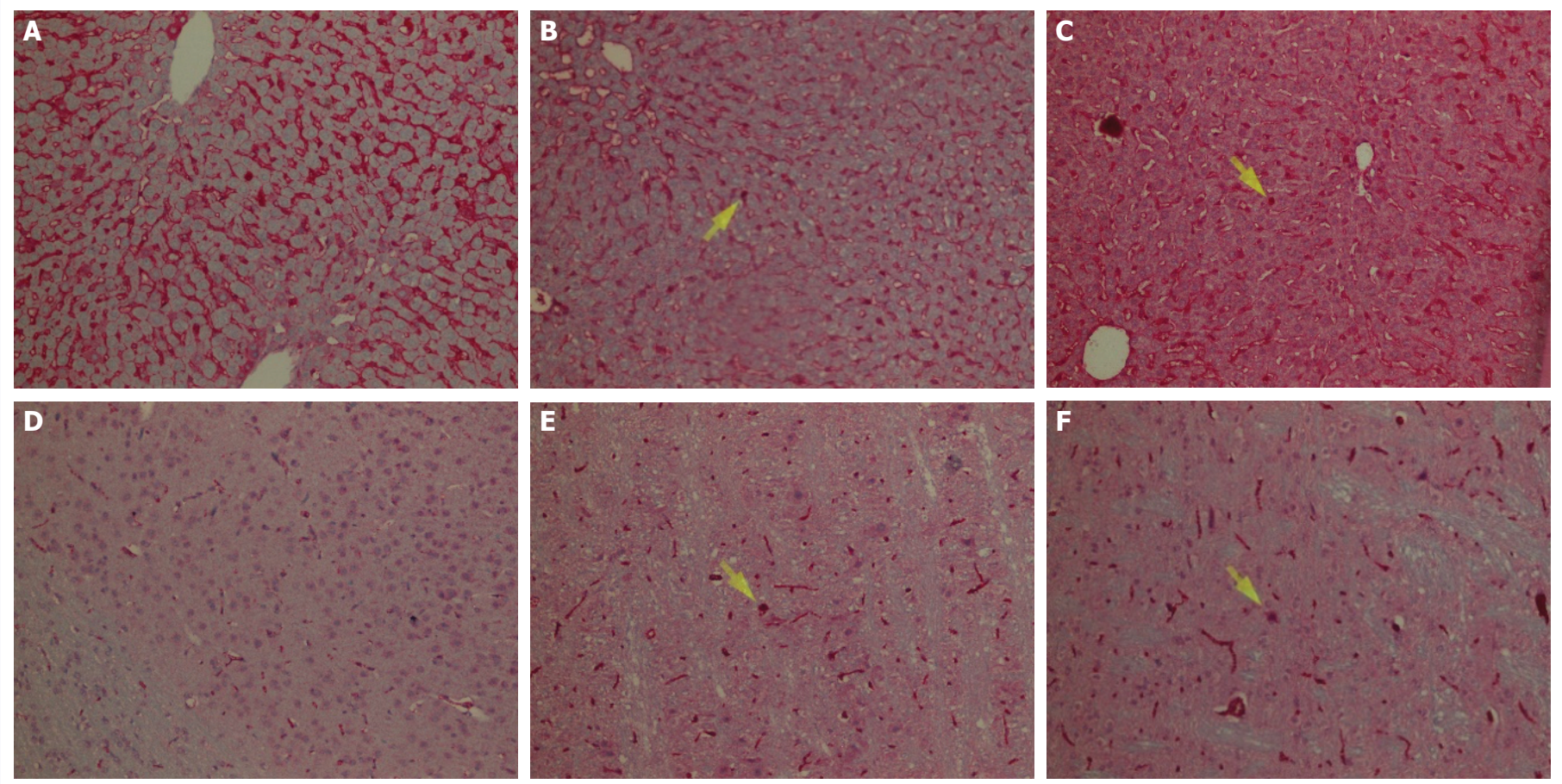

FIGURE 3. Caspase 3 in liver, (A) Control group (B) Low dose 1 day group (C) Low dose 3 day group (caspase 3 score in both groups was statistically higher than control group $p<0.05$ ). Caspase 3 in brain, (D) Control group (E) Low dose 1 day group (F) Low dose 3 day group (no statistically significant difference between groups ( $p>0.05$ ). Immunohistochemical staining ( 200 magnification).
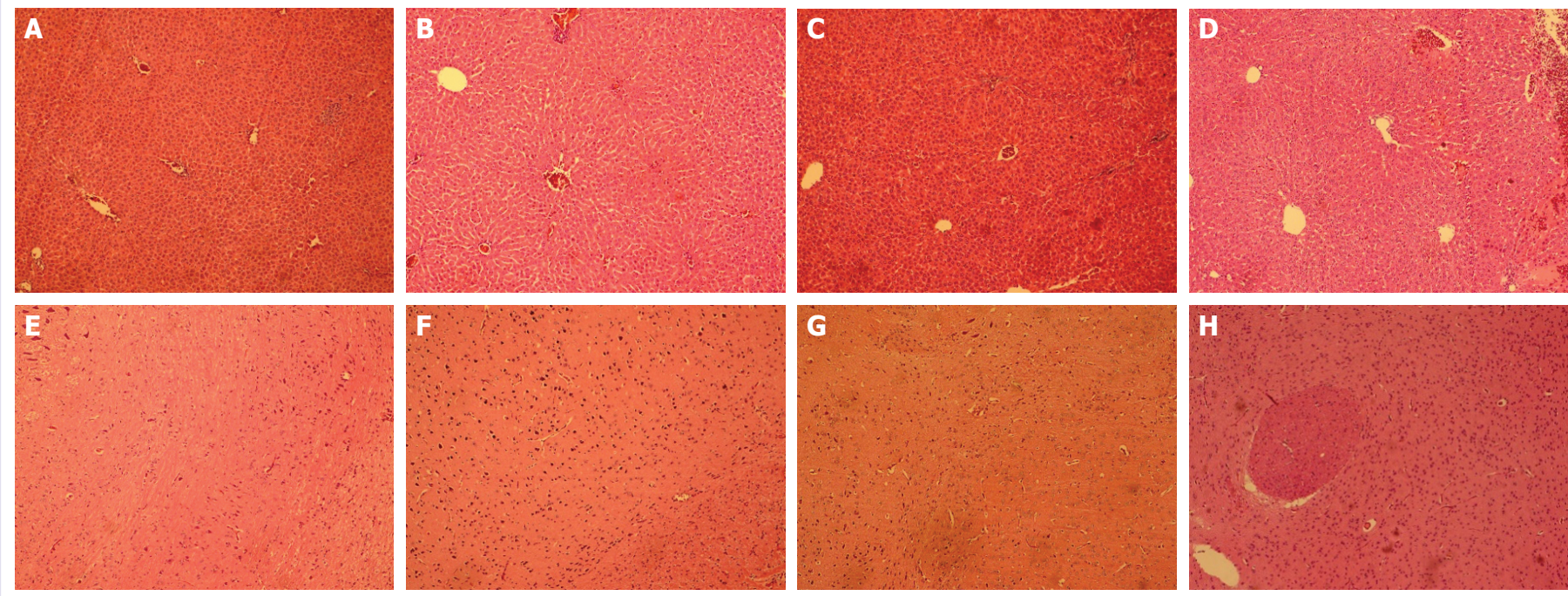

FIGURE 4. Liver and brain sections with hematoxylin eosin staining. Liver, (A) Low dose 1 day group (B) High dose 1 day group (C) Low dose 3 day group (D) High dose 3 day group. Brain (E) Low dose 1 day group (F) High dose 1 day group (G) Low dose 3 day group (H) High dose 3 day group. There is no necrosis all groups in both liver and brain (x400 magnification).

\section{DISCUSSION}

COX-2, which is induced by various pathogens, leads to the formation of $\mathrm{PGE}_{2}$ and microsomal prostaglandin $\mathrm{E}$ synthase-1 (mPGES-1), which are the main factors in the formation of fever and pain. Conventional NSAIDs inhibit the COX-2 enzyme expressed in pathological conditions and reduce fever by decreasing PGE 2 [17]. Paracetamol, similar to NSAIDs, also acts by inhibiting the formation of COX enzyme-bound $\mathrm{PGE}_{2}$. However, 
TABLE 6. TAS- TOS and OSI levels in liver and brain

\begin{tabular}{lccccrc} 
& $\begin{array}{c}\text { Liver TAS } \\
\text { Mean } \pm \text { SD }\end{array}$ & $\begin{array}{c}\text { Liver TOS } \\
\text { Mean } \pm \text { SD }\end{array}$ & $\begin{array}{c}\text { Liver OSI } \\
\text { Mean } \pm \text { SD }\end{array}$ & $\begin{array}{c}\text { Brain TAS } \\
\text { Mean } \pm \text { SD }\end{array}$ & $\begin{array}{c}\text { Brain TOS } \\
\text { Mean } \pm S D\end{array}$ \\
\hline C & $2.74 \pm 0.23^{\mathrm{b}}$ & $18.03 \pm 0.53^{\mathrm{c}}$ & $672.38 \pm 61.46^{\mathrm{b}}$ & $3.80 \pm 0.09^{\mathrm{a}}$ & $18.76 \pm 0.76^{\mathrm{c}}$ & $493.43 \pm 13.98^{\mathrm{b}}$ \\
LD1 & $2.67 \pm 0.18^{\mathrm{b}}$ & $16.53 \pm 0.93^{\mathrm{c}}$ & $629.29 \pm 52.64^{\mathrm{b}}$ & $3.92 \pm 0.12^{\mathrm{a}}$ & $23.20 \pm 1.37^{\mathrm{b}}$ & $594.78 \pm 47.76^{\mathrm{b}}$ \\
LD3 & $3.01 \pm 0.13^{\mathrm{ab}}$ & $23.62 \pm 1.60^{\mathrm{b}}$ & $786.44 \pm 54.71^{\mathrm{b}}$ & $3.29 \pm 0.24^{\mathrm{b}}$ & $24.23 \pm 1.23^{\mathrm{b}}$ & $749.34 \pm 65.52^{\mathrm{b}}$ \\
HD1 & $3.48 \pm 0.19^{\mathrm{a}}$ & $27.11 \pm 1.88^{\mathrm{b}}$ & $780.56 \pm 81.18^{\mathrm{b}}$ & $2.39 \pm 0.11^{\mathrm{c}}$ & $19.37 \pm 1.33^{\mathrm{c}}$ & $816.94 \pm 69.09^{\mathrm{b}}$ \\
HD3 & $3.53 \pm 0.31^{\mathrm{a}}$ & $37.87 \pm 3.10^{\mathrm{a}}$ & $1119.21 \pm 131.90^{\mathrm{a}}$ & $1.94 \pm 0.24^{\mathrm{d}}$ & $38.38 \pm 2.41^{\mathrm{a}}$ & $2061.06 \pm 237.43^{\mathrm{a}}$ \\
\hline
\end{tabular}

TAS: Total antioxidant; TOS: Total oxidant; OSI: Oxidative Stress Index; SD: Standard deviation; C: Control; LD1: Low dose 1-day group; HD1: High dose 1-day group; LD3: Low dose 3-day group; HD3: High-dose 3-day group (HD3) ( $<<0.05) ; a, b$, c: Shows statistically significant difference between groups.

TABLE7. ALT and AST levels in the liver and the brain

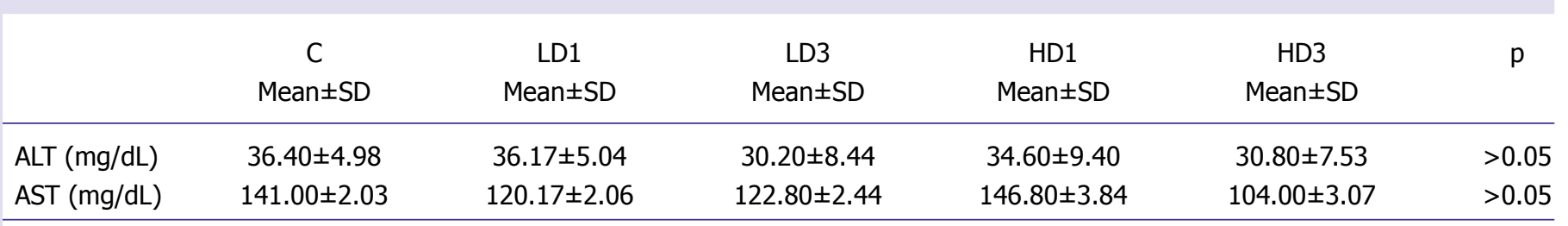

ALT: Alanine aminotransferase; AST: Aspartate aminotransferase; SD: Standard deviation; C: Control; LD1: Low dose 1-day group; HD1: High dose 1-day group; LD3: Low dose 3-day group; HD3: High-dose 3-day group (HD3).

it has been suggested that it has no effect on the COX enzyme in peripheral tissues due to a lack of anti-inflammatory effect [18]. Various studies have supported this claim and found that it does not inhibit COX enzyme in peripheral tissues, such as the stomach [19]. In addition, the absence of side effects of NSAIDs on the gastrointestinal system and hemostasis in paracetamol supported the view that there was no effect on peripheral COX, and its main role was suggested as COX enzyme in CNS. Studies on the subject have shown that lipopolysaccharide-induced fever in CNS is reduced by inhibiting the COX-2 [19]. Paracetamol does not inhibit the peripheral COX enzyme but only conducts central COX enzyme inhibition in two ways. The first is that paracetamol only inhibits the catalytic active form without binding to the active site of the COX enzymes. Peroxidase activity in the COX enzyme is quite high in peripheral tissues compared to the brain. This explains why paracetamol only affects CNS [20]. The other view is that in studies with dogs in the 2000s COX-1 mRNA with two different intron- 1 regions was detected, and a new $\mathrm{COX}-1$ variant encoded by the same gene was found. This new variant of
COX-1 is named COX-3. It has been claimed that this variant, especially found in the brain and spinal cord, may have a role in pain sensitivity and that paracetamol has analgesic and antipyretic effects by inhibiting the COX-3 in CNS [2]. In addition to these two basic mechanisms, paracetamol has been found to have an effect on CNS and different systems. For example, it has been shown to regulate the endogenous cannabinoid system and activate the vanilloid type 1 receptor. This contributes to the analgesic and antipyretic properties of paracetamol. Because of this effect, some patients using paracetamol have been reported to have relaxation, well-being and relief [21,22]. The findings of our study were in contradiction with the publications suggesting that paracetamol acts by inhibiting the COX-3 enzyme in the brain. Although there was no statistically significant difference between the groups in COX-3 enzyme levels in the brain, COX-3 levels were significantly lower in groups treated with high dose paracetamol in the liver compared to the other groups $(p>0.05$, $\mathrm{p}<0.05$, respectively). The similarity of COX -3 levels in the control groups in the liver and brain is also different from the reports that $\mathrm{COX}-3$ is a localized variant only 
in the brain. Although paracetamol inhibits the COX3 enzyme level in the liver at high doses, the absence of any effect in the brain may be due to its effect on the above-mentioned peroxidase catalytic level. In the COX3 enzyme, catalytic activity may be more in the liver, as opposed to COX-2. When $\mathrm{PGE}_{2}$ levels were evaluated, there was no statistically significant difference between groups in both the liver and brain. However, only the percentage of $\mathrm{PGE}_{2}$ in the brain was significantly lower in the LD 3 and $\mathrm{HD} 3$ groups than in the $\mathrm{C}$ and LD1 groups. Although paracetamol inhibits the COX-3 enzyme in the liver, it does not change the $\mathrm{PGE}_{2}$ level, indicating that the COX-3 enzyme has no effect on the basal $\mathrm{PGE}_{2}$ level. These results also support studies that paracetamol has no effect on peripheral $\mathrm{PGE}_{2}$. However, in our study, basal COX -3 and $\mathrm{PGE}_{2}$ levels were evaluated, so new studies are needed to investigate the effects of paracetamol on the all COX enzymes $(1,2,3)$ and $\mathrm{PGE}_{2}$ levels in all central and peripheral tissues in pathological conditions induced by various pathogens, such as LPS and fever.

$\mathrm{NAB}$ after high-dose paracetamol causes toxicity in hepatocytes by several chain mechanisms. First, NAB inhibits $\mathrm{Ca}-\mathrm{Mg} / \mathrm{ATP}$-ase pump in membranes, leading to intracellular calcium $(\mathrm{Ca})$ deposition Accumulated Ca causes calpain activation, while calpain may lead to degradation of structural proteins in hepatocytes and consequently to necrosis. The second mechanism is increased ROS, which plays a major role in paracetamol toxicity. Nitric oxide (NO) has been shown to be the most important of the ROS formed in various studies. $\mathrm{NO}$ is converted to toxic peroxynitrite, which causes cellular damage to mitochondria with superoxides. Furthermore, oxidative stress leads to increased mitochondrial membrane permeability (MPT) in the cells, resulting in mitochondrial swelling, mitochondrial pore opening, caspase 3 activation through cytochrome $\mathrm{C}$, and apoptosis $[18$, 23]. However, decreased ATP in the cells due to toxicity inhibits apoptosis, leading to direct necrosis of the cells [24]. In recent years, two different mechanisms have been proposed in liver toxicity caused by paracetamol. ROS has been shown to cause Mitogen-Activated Protein Kinases (MAPK) activation, while MAPK phosphorylates $c$-Jun $\mathrm{N}$-terminal kinase (JNK), known as the death receptor in cells, causing necrosis via MPT [9, 25]. Another mechanism is necrosis caused by the activation of protein Kinase-1 (RIPK1) and RIPK3 protein complex [26]. Although liver toxicity of paracetamol is well known, our study contributes to show that there are different mechanisms of this toxicity. For example, as the team designing the experiment, although intraperitoneal administration of paracetamol at a dose of $500 \mathrm{mg} / \mathrm{kg}$, consistent with the literature, we found no necrosis in the liver interestingly. The fact that ALT and AST values do not increase in parallel supports that necrosis does not occur. The absence of hepatotoxicity may be caused by a genetic variation that we could not predict in the rats we used in the experiment, or it could have prevented damage by the presence of different mechanisms at high doses. However, the necessity of reevaluating the dose of paracetamol causing liver toxicity is not overlooked. Although there was no necrosis, the caspase 3 enzyme was significantly higher in the low dose groups compared to the other groups $(\mathrm{p}<0.05)$. This suggests that liver toxicity may be caused by apoptosis in cells in low-dose paracetamol. The absence of apoptosis at high doses may be due to the above mentioned ATP reduction. In accordance with the literature showing that paracetamol causes liver damage via free oxygen radicals, the results of our study present that the OSI value in the HD3 group was statistically significantly higher than the other groups $(\mathrm{p}<0.05)$. However, the lack of necrosis despite this increased OSI value suggests that there may be other mechanisms in liver toxicity caused by paracetamol from those known to date. Comprehensive studies on this subject are planned.

Another organ with the toxic effects of paracetamol is the brain. Ammonia (NH4), which cannot be converted to a non-ionized (NH3) form due to ALF, easily penetrates the CNS, where it is converted to glutamine formation by glutamine synthase. Increased glutamine causes osmotic stress and astrocyte toxicity. This phenomenon is the main mechanism of paracetamol toxicity [18]. However, paracetamol directly increases ROS and oxidative stress even without ALF, causing toxicity in CNS [9]. In mice, toxic doses of paracetamol increased ROS and decreased $\mathrm{Na} / \mathrm{K}$ ATPase activity and impaired mitochondrial functions [27]. Similarly, in a recently published study, paracetamol at a dose of $1 \mathrm{~g} /$ $\mathrm{kg}$ has been shown to have toxic effects on neuron cells without ALF. Again in this study, rats were hypoactive due to the inhibitory effects of paracetamol on the dopaminergic pathway and dopamine [28]. In a different study, paracetamol caused neuronal damage in the rat brain dose dependently. In the same study, it was shown to increase apoptosis via cytochrome $c$ and caspase 3 depending on the dose and time in cortical neuron cell culture in vitro [29]. In addition, paracetamol has been shown to increase ROS and decrease cell proliferation in 
various CNS-derived tumor cell lines, such as neuroblastoma [30]. However, there are studies that paracetamol has opposite or paradoxical effects on brain cells. For example, paracetamol at a dose of $15 \mathrm{mg} / \mathrm{kg}$ was found to reduce brain damage and apoptosis after hypovolemia [31]. Again, in mice, it was found that paracetamol corrected LPS-induced inflammation, neuronal damage and impaired cognitive functions by reducing oxidative stress and apoptosis [32]. Similarly, in a study on hippocampal cell culture, it was shown that paracetamol protects cells and reduces apoptosis by reducing oxidative stress and lipid peroxidation [15]. The results of our study differ slightly from the above-mentioned studies. There was no difference in the levels of apoptosis in the brain between the paracetamol and control groups $(p>0.05)$. These results show that, unlike the liver, paracetamol has no effect on apoptosis in the brain in our study. However, similar to the liver, the levels of OSI in the brain were significantly higher than in the other groups, especially in high-dose groups, and this value was almost twice that of the liver. These results suggest that the toxicity that may occur as a result of oxidative stress in the brain may be much higher than the liver. The lack of apoptosis, although the OSI is so high, maybe due to ATP deficiency as in the liver. The absence of necrosis also suggests that there are many mechanisms that need to be investigated differently, as in the liver. In addition, the decrease in feeding, drinking and activity of rats in the HD3 group supports the studies on the effects of paracetamol on the cannabinoid system or dopaminergic system.

\section{Conclusion}

The findings obtained in this study suggest that COX3 enzyme is expressed in peripheral and CNS, paracetamol inhibits this enzyme in the liver but has no effect on the level of COX-3 in the brain. Again, no change in $\mathrm{PGE}_{2}$ level indicates that COX-3 enzyme had no effect on $\mathrm{PGE}_{2}$ production. It also shows that paracetamol causes apoptosis in the liver, even at low doses, and may cause toxicity by increasing ROS in the brain, especially at higher doses.

Acknowledgements: We would like to thank Zihni Yigit Oksuz from University British Columbia for his contribution to the experimental procedure and Sadi Elasan from Van Yuzuncu Yil University Medical Faculty, Department of Biostatistics for his contribution to manuscript.

Ethics Committee Approval: The Van Yuzuncu Yil University Animal Ethics Committee granted approval for this study (date: 06.07.2017, number: 2017/06).
Conflict of Interest: No conflict of interest was declared by the authors.

Financial Disclosure: This study was supported by scientific research projects of Van Yuzuncu Yil University with the project number TSA-2017-6377.

Authorship Contributions: Concept - EO; Data collection and/or processing - EO, SY, OK, GO; Analysis and/or interpretation - EO, SY, RE; Literature review - EO, SY, GO, OA; Writing - EO; Critical review - EO, SY, RE, GO, OA.

\section{REFERENCES}

1. Bertolini A, Ferrari A, Ottani A, Guerzoni S, Tacchi R, Leone S. Paracetamol: new vistas of an old drug. CNS Drug Rev 2006;12:250-75.

2. Chandrasekharan NV, Dai H, Roos KL, Evanson NK, Tomsik J, Elton TS, et al. COX-3, a cyclooxygenase- 1 variant inhibited by acetaminophen and other analgesic/antipyretic drugs: cloning, structure, and expression. Proc Natl Acad Sci U S A 2002;99:13926-31. [CrossRef]

3. Kis B, Snipes JA, Busija DW. Acetaminophen and the cyclooxygenase-3 puzzle: sorting out facts, fictions, and uncertainties. J Pharmacol Exp Ther 2005;315:1-7. [CrossRef]

4. Li S, Dou W, Tang Y, Goorha S, Ballou LR, Blatteis CM. Acetaminophen: antipyretic or hypothermic in mice? In either case, PGHS-1b (COX-3) is irrelevant. Prostaglandins Other Lipid Mediat 2008;85:89-99. [CrossRef]

5. Davis M, Labadarios D, Williams RS. Metabolism of paracetamol after therapeutic and hepatotoxic doses in man. J Int Med Res 1976;4:40-5.

6. Mitchell JR, Jollow DJ, Potter WZ, Gillette JR, Brodie BB. Acetaminophen-induced hepatic necrosis. IV. Protective role of glutathione. J Pharmacol Exp Ther 1973;187:211-7.

7. Burcham PC, Harman AW. Acetaminophen toxicity results in site-specific mitochondrial damage in isolated mouse hepatocytes. J Biol Chem 1991;266:5049-54.

8. Tsokos-Kuhn JO, Hughes H, Smith CV, Mitchell JR. Alkylation of the liver plasma membrane and inhibition of the Ca2+ ATPase by acetaminophen. Biochem Pharmacol 1988;37:2125-31. [CrossRef]

9. Isobe-Harima Y, Terai S, Miura I, Segawa M, Murata T, Itamoto K, et al. A new hepatic encephalopathy model to monitor the change of neural amino acids and astrocytes with behaviour disorder. Liver Int 2008;28:117-25. [CrossRef]

10. Aggarwal S, Kramer D, Yonas H, Obrist W, Kang Y, Martin M, et al. Cerebral hemodynamic and metabolic changes in fulminant hepatic failure: a retrospective study. Hepatology 1994;19:80-7. [CrossRef]

11. Upadhya SC, Tirumalai PS, Boyd MR, Mori T, Ravindranath V. Cytochrome P4502E (CYP2E) in brain: constitutive expression, induction by ethanol and localization by fluorescence in situ hybridization. Arch Biochem Biophys 2000;373:23-34. [CrossRef]

12. Courad JP, Besse D, Delchambre C, Hanoun N, Hamon M, Eschalier A, et al. Acetaminophen distribution in the rat central nervous system. Life Sci. 2001;69:1455-64. [CrossRef]

13. Micheli L, Fiaschi AI, Cerretani D, Giorgi G. Effect of acetaminophen on glutathione levels in several regions of the rat brain. Curr Ther Res 1993;53:730-6. [CrossRef]

14. Naziroğlu M, Uğuz AC, Koçak A, Bal R. Acetaminophen at different doses protects brain microsomal Ca2+-ATPase and the antioxidant redox system in rats. J Membr Biol 2009;231:57-64. [CrossRef]

15. Bisaglia M, Venezia V, Piccioli P, Stanzione S, Porcile C, Russo C, et al. Acetaminophen protects hippocampal neurons and PC12 cultures 
from amyloid beta-peptides induced oxidative stress and reduces NFkappaB activation. Neurochem Int 2002;41:43-54. [CrossRef]

16. Erel O. A new automated colorimetric method for measuring total oxidant status. Clin Biochem 2005;38:1103-11. [CrossRef]

17. Vane JR. Inhibition of prostaglandin synthesis as a mechanism of action for aspirin-like drugs. Nat New Biol 1971;231:232-5. [CrossRef]

18. Ghanem CI, Pérez MJ, Manautou JE, Mottino AD. Acetaminophen from liver to brain: New insights into drug pharmacological action and toxicity. Pharmacol Res 2016;109:119-31. [CrossRef]

19. Engström Ruud L, Wilhelms DB, Eskilsson A, Vasilache AM, Elander L, Engblom D, et al. Acetaminophen reduces lipopolysaccharideinduced fever by inhibiting cyclooxygenase-2. Neuropharmacology 2013;71:124-9. [CrossRef]

20. Boutaud O, Aronoff DM, Richardson JH, Marnett LJ, Oates JA. Determinants of the cellular specificity of acetaminophen as an inhibitor of prostaglandin $\mathrm{H}(2)$ synthases. Proc Natl Acad Sci U S A 2002;99:7130-5. [CrossRef]

21. Stockler M, Vardy J, Pillai A, Warr D. Acetaminophen (paracetamol) improves pain and well-being in people with advanced cancer already receiving a strong opioid regimen: a randomized, double-blind, placebocontrolled cross-over trial. J Clin Oncol 2004;22:3389-94. [CrossRef]

22. Sima L, Fang WX, Wu XM, Li F. Efficacy of oxycodone/paracetamol for patients with bone-cancer pain: a multicenter, randomized, double-blinded, placebo-controlled trial.J Clin Pharm Ther 2012;37:27-31.

23. Guo C, Xie G, Su M, Wu X, Lu X, Wu K, et al. Characterization of acetaminophen-induced cytotoxicity in target tissues. Am J Transl Res 2016;8:4440-5.

24. Cover C, Mansouri A, Knight TR, Bajt ML, Lemasters JJ, Pessayre D, et al. Peroxynitrite-induced mitochondrial and endonuclease-mediated nuclear DNA damage in acetaminophen hepatotoxicity. J Pharmacol Exp Ther 2005;315:879-87. [CrossRef]
25. Sun Y, Li TY, Song L, Zhang C, Li J, Lin ZZ, et al. Liver-specific deficiency of unc-51 like kinase 1 and 2 protects mice from acetaminopheninduced liver injury. Hepatology 2018;67:2397-413. [CrossRef]

26. Ghanem CI, Rudraiah S, Bataille AM, Vigo MB, Goedken MJ, Manautou JE. Role of nuclear factor-erythroid 2-related factor $2(\mathrm{Nrf} 2)$ in the transcriptional regulation of brain $\mathrm{ABC}$ transporters during acute acetaminophen (APAP) intoxication in mice. Biochem Pharmacol 2015;94:203-11. [CrossRef]

27. da Silva MH, da Rosa EJ, de Carvalho NR, Dobrachinski F, da Rocha JB, Mauriz JL, et al. Acute brain damage induced by acetaminophen in mice: effect of diphenyl diselenide on oxidative stress and mitochondrial dysfunction. Neurotox Res 2012;21:334-44. [CrossRef]

28. Vigo MB, Pérez MJ, De Fino F, Gómez G, Martínez SA, Bisagno V, et al. Acute acetaminophen intoxication induces direct neurotoxicity in rats manifested as astrogliosis and decreased dopaminergic markers in brain areas associated with locomotor regulation. Biochem Pharmacol 2019;170:113662. [CrossRef]

29. Posadas I, Santos P, Blanco A, Muñoz-Fernández M, Ceña V. Acetaminophen induces apoptosis in rat cortical neurons. PLoS One 2010;5:e15360. [CrossRef]

30. Posadas I, Vellecco V, Santos P, Prieto-Lloret J, Ceña V. Acetaminophen potentiates staurosporine-induced death in a human neuroblastoma cell line. Br J Pharmacol 2007;150:577-85. [CrossRef]

31. Baliga SS, Jaques-Robinson KM, Hadzimichalis NM, Golfetti R, Merrill GF. Acetaminophen reduces mitochondrial dysfunction during early cerebral postischemic reperfusion in rats. Brain Res 2010;1319:14254. [CrossRef]

32. Zhao WX, Zhang JH, Cao JB, Wang W, Wang DX, Zhang XY, et al. Acetaminophen attenuates lipopolysaccharide-induced cognitive impairment through antioxidant activity. J Neuroinflammation 2017;14:17. [CrossRef] 